\title{
Formulasi Mouthwash Ekstrak Kulit Buah Nanas (Ananas comosus (L.) Merr) dengan Variasi Konsentrasi Gliserin sebagai Antibakteri Terhadap Streptococcus mutans ATCC 25175
}

\section{Mouthwash Formulation of Pineapple Skin Extract (Ananas comosus (L.) Merr) with Variations of Glycerine Concentration as an Antibacterial Against Streptococcus mutans ATCC 25175}

\author{
Novita Maharani, Siti Aisiyah, Desi Purwaningsih \\ Email: novitamaharani732@gmail.com \\ ${ }^{1}$ Jurusan S1 Farmasi, Fakultas Farmasi, Universitas Setia Budi Surakarta \\ Riwayat Artikel: Diterima September 2021; Diterbitkan Oktober 2021
}

\begin{abstract}
Abstrak
Karies gigi menjadi penyakit utama dalam permasalahan pada rongga mulut terutama pada gigi. Penyebab utama terjadinya karies gigi adalah bakteri Streptococcus mutans yang menjadi penghuni normal pada rongga mulut. Karies gigi dapat diatasi menggunakan suatu sediaan mouthwash yang mengandung zat antibakteri. Kulit buah nanas (Ananas comosus (L.) Merr) merupakan salah satu tanaman yang memiliki kandungan zat yang memiliki aktivitas sebagai antibakteri. Tujuan dari penelitian ini adalah untuk mengetahui mutu fisik dan stabilitas, serta aktivitas antibakteri mouthwash ekstrak kulit buah nanas.

Ekstrak kulit buah nanas dibuat dalam tiga formula sediaan mouthwash menggunakan variasi konsentrasi gliserin 5\%, 10\%, dan 15\%. Sediaan mouthwash diuji mutu fisik dan stabilitas. Uji aktivitas antibakteri terhadap Streptococcus mutans ATCC 25175 menggunakan metode sumuran. Data yang didapat disajikan dalam bentuk tabel dan grafik diolah dengan SPSS ver22 dengan metode Paired T-Test pada pengujian viskositas dan pengujian $\mathrm{pH}$ dan ANOVA pada pengukuran diameter zona hambat.

Hasil penelitian menunjukan bahwa sediaan mouthwash pada semua formula dengan mutu fisik organoleptik, viskositas, dan stabilitas menghasilkan sediaan yang baik, sedangkan pada pengujian mutu fisik $p \mathrm{H}$ tidak memenuhi syarat $p \mathrm{H}$ sediaan mouthwash karena pengaruh dari ekstrak kulit buah nanas (Ananas comosus (L.) Merr). Pada pengujian aktivitas antibakteri sediaan mouthwash didapatkan nilai diameter zona hambat yaitu basis 0 mm; F1 11,08 mm; F2 13,08 mm; F3 15,08 mm; dan kontrol positif $16,75 \mathrm{~mm}$.
\end{abstract}

Kata kunci : karies; nanas; mouthwash; Streptococcus mutans.

\begin{abstract}
Dental caries is a major disease in problems in the oral cavity especially in the teeth. The main cause of dental caries is the bacterium Streptococcus mutans which is a normal inhabitant of the oral cavity. Dental caries can be overcome using a mouthwash preparation containing antibacterial substances. Pineapple skin (Ananas comosus (L.) Merr) is one of the plants that contains substances that have antibacterial activity. The purpose of this study was to determine the physical quality and stability, and activity antibacterial of mouthwash pineapple skin extract.
\end{abstract}



Pineapple skin extract was made in three mouthwash formulations using various concentrations of glycerin 5\%,10\%, and 15\%. Mouthwash were tested for physical quality and stability. Antibacterial activity test against Streptococcus mutans ATCC 25175 using the well method. The data obtained are presented in the form of tables and graphs processed with SPSS ver22 with the Paired T-Test method for testing viscosity and testing $\mathrm{pH}$ and ANOVA for measuring the diameter of the inhibition zone.

The results showed that mouthwash preparations in all formulas with organoleptic physical qualities, viscosity, and stability produced good preparations, while in testing the physical quality of the $\mathrm{pH}$ did not meet the $\mathrm{pH}$ requirements of mouthwash preparations because of the influence of pineapple skin extract (Ananas comosus (L.) Merr). In testing the antibacterial activity of mouthwash, the diameter of the inhibition zone was obtained the base $0 \mathrm{~mm}$; F1 $11.08 \mathrm{~mm}$; F2 $13.08 \mathrm{~mm}$; F3 $15.08 \mathrm{~mm}$; and control positive 16,75 $\mathrm{mm}$.

Keywords : caries; pineapple; mouthwash; Streptococcus mutans.

\section{Pendahuluan}

Kesehatan mulut harus dijaga agar terhindar dari masalah kesehatan yang dapat menurunkan kepercayaan diri seseorang. Masalah pada mulut dapat membatasi pada saat menggigit, mengunyah, tersenyum, dan berbicara (WHO, 2012). Masalah yang berhubungan dengan mulut sering terjadi dalam kehidupan manusia salah satunya yaitu bau mulut yang disebabkan karena karies gigi (Pradewa, 2018).

Karies gigi merupakan penyakit yang terjadi pada rongga mulut khususnya pada gigi yang disebabkan oleh bakteri Streptococcus mutans ATCC 25175 yang menjadi penghuni normal pada rongga mulut. Streptococcus mutans ATCC 25175 dapat bersifat patogen apabila lingkungan hidup bakteri menguntungkan (Kidd dan Bechal, 1992).

Salah satu untuk mengatasi timbulnya plak pada gigi yang dapat menyebabkan karies gigi yaitu menggunakan suatu sediaan mouthwash yang mengandung suatu zat antibakteri. Mouthwash merupakan suatu larutan yang mengandung berbagai bahan yang digunakan untuk memberi rasa segar dan membersihkan rongga mulut yang penggunaanya dengan cara kumur (Akarina, 2011). Penggunaan mouthwash dapat membantu membersihkan sisa-sisa makanan yang menempel di rongga mulut dibandingkan hanya dengan menggosok gigi saja.

Zat aktif pada formula mouthwash yang memiliki aktivitas antibakteri dapat berasal dari bahan sintetis maupun bahan alam. Bahan alam relatif lebih dipilih karena lebih aman, mempunyai efek samping tertentu, dan jarang ditemukan menimbulkan efek samping yang merugikan dibanding dengan bahan sintetis (Dewi, 2019). Salah satu bahan alam yang dapat digunakan sebagai zat aktif pada formula mouthwash adalah kulit buah nanas (Ananas comosus (L.) Merr).

Kulit buah nanas mengandung senyawa fenolik seperti flavonoid, tanin, saponin dan alkaloid yang memiliki efek menekan pertumbuhan bakteri. Selain senyawa fenolik kulit buah nanas juga mengandung enzim bromelain yang memiliki aktivitas sebagai antibakteri. Ekstrak kulit buah nanas pada konsentrasi $6,25 \%$ bersifat sebagai bakteriostatik (Angraeni dan Rahmawati, 2012).

Kandungan selain zat aktif yang juga memiliki peran penting untuk menghasilkan sediaan mouthwash yang baik adalah humektan. Gliserin adalah humektan yang sering digunakan pada sediaan mouthwash. Humektan sangat berpengaruh terhadap mutu fisik dan stabilitas sediaan mouthwash yang dihasilkan. Humektan memiliki fungsi untuk menjaga zat aktif dan kandungan lain dalam sediaan mouthwash tidak menguap sehingga kontak zat aktif pada gigi akan lama dan untuk memperbaiki stabilitas dalam jangka panjang (Akarina, 2011). Formulasi mouthwash ekstrak kulit buah nanas dengan konsentrasi gliserin sebesar 15\% menghasilkan mutu fisik yang baik. Penggunaan gliserin berpengaruh terhadap mutu fisik organoleptik, $p \mathrm{H}$, viskositas, dan stabilitas dari sediaan mouthwash (Baitariza et al., 2020). Pada penelitian-penelitian sebelumnya, ekstrak kulit buah nanas sudah dikembangkan atau diteliti dalam bentuk sediaan lotion, krim tabir surya, gel, hand sanitizer, dan lain-lain. Adapun tujuan dari penelitian ini adalah untuk mengembangkan ekstrak kulit buah nanas 
dalam sediaan mouthwash dan untuk mengetahui mutu fisik dan stabilitas, serta aktivitas antibakteri mouthwash ekstrak kulit buah nanas.

\section{Metode Penelitian}

\subsection{Waktu dan Tempat}

Penelitian ini dilakukan di Laboratorium Biologi Farmasi, Teknologi Farmasi, dan Mikrobiologi Fakultas Farmasi, Universitas Setia Budi Surakarta. Penelitian dimulai pada bulan Januari 2021 sampai bulan April 2021.

\subsection{Alat dan Bahan}

Alat yang digunakan dalam penelitian ini adalah neraca analitik (Ohaus $\left.{ }^{\circledR}\right)$, alat-alat gelas (Pyrex $\left.{ }^{\circledR}\right)$, cawan porselin, batang pengaduk, tabung reaksi (Pyrex $\AA)$, corong kaca, botol coklat maserasi, kurs porselin, ayakan, rotary evaporator (Heidolph $\left.{ }^{\circledR}\right), \quad$ oven (Memmert $\left.{ }^{\circledR}\right)$, moisture balance (Ohaus $\left.{ }^{\circledR}\right)$, autoclave, incubator (Memmert $\left.{ }^{\circledR}\right)$, cawan petri, mikropipet, perforator, viskometer, $p \mathrm{H}$ meter (Eutech $\AA$ ), centrifuge (Gemmy PLC-03®), mikroskop, jarum ose, object glass, deck glass, bunsen, Laminar Air Flow (LAF).

Bahan yang digunakan dalam penelitian ini adalah ekstrak kulit buah nanas, bakteri Streptococcus mutans ATCC 25175, etanol 96\% (PT. Nissichem), etanol 70\%, gliserin (PT. Brataco), sodium sakarin (Lux Chemicals), natrium benzoat (Making Cosmetics), oleum menthae (Cipta Kimia), tween 80 (Avantor), aqua destilata (Lux Chemicals), spiritus, $\mathrm{NaCl}$, reagen Dragendorff, reagen Mayer, reagen Bouchardat, serbuk magnesium, asam klorida, $\mathrm{H}_{2} \mathrm{SO}_{4}$ pekat, larutan ninhidrin, $\mathrm{FeCl}_{3}$, Mueller Hinton Agar, Brain Heart Infusion, Nutrient Agar, crystal violet, lugol, aseton, safranin.

\subsection{Cara Kerja}

\subsubsection{Determinasi tanaman}

Determinasi tanaman dilakukan untuk mengetahui kebenaran tanaman berkaitan dengan ciri-ciri dan morfologi yang ada pada tanaman nanas dibuktikan di Laboratorium Biologi Farmasi Universitas Setia Budi Surakarta.

\subsubsection{Pengumpulan sampel}

Sampel kulit buah nanas dipilih yang masih segar, berwarna kuning, tidak busuk, serta terbebas dari hama yang diperoleh dari Pemalang Jawa Tengah.

\subsubsection{Penyiapan simplisia}

Dilakukan sortasi basah, dicuci, dirajang, lalu dikeringkan di bawah sinar matahari dengan ditutup kain hitam sampai kering dengan waktu pengeringan selama 1 minggu, kemudian dilakukan sortasi kering. Sampel dihaluskan dengan cara digiling dengan grinder, kemudian dilakukan pengayakan dengan pengayak no 40 hingga diperoleh serbuk yang halus dan homogen.

\subsubsection{Penetapan kelembaban serbuk}

Penetapan kelembaban serbuk dilakukan menggunakan alat moisture balance dengan tujuan untuk mengetahui rentang besarnya senyawa yang hilang pada proses pengeringan. Alat dinyalakan kemudian suhu diatur $105^{\circ} \mathrm{C}$ lalu ditimbang serbuk sebanyak 2 gram langsung pada alat moisture balance, kemudian menutup rapat alat dan menunggu hingga diperoleh kadar kelembaban serbuk kulit buah nanas yang konstan. Dilakukan replikasi sebanyak 3 kali (Dewi, 2019).

1.3.5 Pembuatan ekstrak kulit buah nanas

Serbuk kulit buah nanas ditimbang sebanyak 1000 gram, kemudian dimaserasi dengan etanol 96\% sebanyak 10 liter. Direndam ditutup rapat serta terhindar dari cahaya matahari langsung. Direndam selama 6 jam pertama sambil sesekali diaduk, kemudian didiamkan selama 18 jam. Maserat disaring. Proses maserasi diulangi sebanyak satu kali (remaserasi) dengan jenis pelarut yang sama dan jumlah volume pelarut sebanyak setengah kali jumlah volume pelarut pada maserasi (5 liter) dan direndam selama 24 jam. Maserat dikumpulkan, lalu diuapkan dengan rotary evaporator, kemudian dimasukkan oven dengan suhu kurang dari $60^{\circ} \mathrm{C}$ sampai diperoleh ekstrak kental. Kadar ekstrak dinyatakan dalam \% (b/b) (Kemenkes RI, 2017).

$$
\begin{aligned}
& \% \text { rendemen }=\frac{\text { Bobot ekstrak }(g)}{\text { Bobot simplisia }(g)} \times 100 \% \\
& \text { 1.3.6 Identifikasi kandungan senyawa } \\
& \text { kimia ekstrak kulit buah nanas }
\end{aligned}
$$

a. Uji flavonoid. 1 gram ekstrak dilarutkan dengan $20 \mathrm{ml}$ air panas lalu didinginkan dan disaring. $5 \mathrm{ml}$ filtrat dimasukkan dalam tabung reaksi ditambahkan 5 tetes $\mathrm{H}_{2} \mathrm{SO}_{4}$ pekat. Terbentuk warna merah menunjukkan sampel mengandung senyawa flavonoid (Sangi et al., 2008). 
b. Uji tanin. 1 gram ekstrak dilarutkan dengan $20 \mathrm{ml}$ air panas, lalu didinginkan dan disaring. $5 \mathrm{ml}$ filtrat dimasukkan ke dalam tabung reaksi ditambah dengan 3

c. Uji saponin. 1 gram ekstrak kulit buah nanas dimasukkan ke dalam tabung reaksi ditambahkan $20 \mathrm{ml}$ air panas, kemudian kocok kuat-kuat selama 10 detik. Positif mengandung saponin jika terbentuk busa setinggi $1-10 \mathrm{~cm}$ selama tidak kurang dari 10 menit dan pada penambahan 1 tetes $\mathrm{HCl} 2 \mathrm{~N}$ busa tidak hilang (Utami et al., 2016).

d. Uji alkaloid. 1 gram ekstrak kulit buah nanas dilarutkan dengan $20 \mathrm{ml}$ air panas kemudian didinginkan dan disaring dan diambil filtratnya, kemudian dimasukkan ke dalam tiga tabung reaksi berbeda yang mana masing-masing sebanyak $2 \mathrm{ml}$, lalu ditambahkan dengan $1 \mathrm{ml} \mathrm{HCl} 2 \mathrm{~N}$. Tabung I ditambahkan 3 tetes reagen Mayer, kemudian hasil positif apabila larutan terbentuk endapan putih. Tabung II ditambahkan 3 tetes reagen Bouchardat, kemudian hasil positif apabila larutan terbentuk endapan jingga hingga coklat. Tabung III ditambahkan 3 tetes reagen Dragendorff, kemudian hasil positif apabila larutan terbentuk endapan jingga (Setiawan, 2016).

e. Uji bromelain. 0,5 gram ekstrak kental kulit buah nanas dilarutkan dengan $10 \mathrm{ml}$ air panas pada cawan porselin, kemudian ditunggu dingin. Ditambah larutan ninhidrin. Campuran dipanaskan pada suhu $100^{\circ} \mathrm{C}$ selama 15 menit sehingga muncul warna ungu yang menandakan terjadinya adanya reaksi dengan larutan ninhidrin. Bromelain positif jika terjadi warna ungu (Pambudi, 2017). tetes pereaksi $\mathrm{FeCl}_{3}$ 1\%. Tanin positif apabila berbentuk warna hijau kehitaman pada reaksi dengan $\mathrm{FeCl}_{3}$ (Depkes RI, 1995).

1.3.7 Penetapan kadar air ekstrak kulit buah nanas

Penetapan kadar air ekstrak kulit buah nanas menggunakan metode gravimetri hingga diperoleh selisih 2 penimbangan berturut-turut tidak lebih dari 0,25\%. Dilakukan replikasi sebanyak 3x (Kemenkes RI, 2017).

\subsubsection{Pengujian bebas etanol}

Uji bebas etanol dilakukan untuk memastikan bahwa ekstrak sudah tidak mengandung etanol. Uji bebas etanol dilakukan dengan cara esterifikasi etanol yaitu 1 gram ekstrak ditambah asam asetat dan asam sulfat kemudian dipanaskan bila tidak ada bau ester berarti sudah tidak ada etanol (Depkes RI, 1986).

1.3.9 Formulasi sediaan mouthwash ekstrak kulit buah nanas

Pertama botol ditara, lalu semua bahan yang akan digunakan dalam pembuatan sediaan mouthwash ditimbang. Natrium benzoat dan sodium sakarin dilarutkan dengan sedikit aqua destilata diaduk hingga larut (campuran 1). Ekstrak kulit buah nanas dan oleum menthae ditambahkan tween 80 diaduk sampai homogen, kemudian ditambahkan gliserin sedikit demi sedikit dan diaduk hingga homogen (campuran 2). Campuran 1 ditambahkan sedikit demi sedikit dalam campuran 2 sambil diaduk hingga homogen, kemudian dimasukkan ke dalam botol. Ditambahkan aqua destilata hingga 100 gram, kemudian dikocok dan botol ditutup rapat. Perlakuan diulang untuk formula yang lain.

Tabel 1. Rancangan formula mouthwash ekstrak kulit buah nanas

\begin{tabular}{|c|c|c|c|c|c|}
\hline \multirow[t]{2}{*}{ Bahan } & \multicolumn{4}{|c|}{ Formula } & \multirow[t]{2}{*}{ Kegunaan } \\
\hline & F0 (\%) & F1 (\%) & F2 (\%) & F3 (\%) & \\
\hline Ekstrak kulit buah nanas & - & 6,25 & 6,25 & 6,25 & Zat aktif \\
\hline Gliserin & 5 & 5 & 10 & 15 & Humektan \\
\hline Natrium benzoate & 0,1 & 0,1 & 0,1 & 0,1 & Pengawet \\
\hline Tween 80 & 1 & 1 & 1 & 1 & Penstabil/emulgator \\
\hline Sodium sakarin & 0,1 & 0,1 & 0,1 & 0,1 & Flavoring agent \\
\hline Oleum menthae & 0,3 & 0,3 & 0,3 & 0,3 & Flavoring agent \\
\hline Aqua destilata ad & 100 & 100 & 100 & 100 & Pelarut \\
\hline
\end{tabular}

F0 : Kontrol negatif (sediaan mouthwash tanpa ekstrak) dengan konsentrasi gliserin 5\%; K+ : Kontrol positif colgate; F1: Formula 1 mouthwash ekstrak kulit buah nanas dengan konsentrasi gliserin 5\%; F2 : Formula 2 mouthwash ekstrak kulit buah nanas dengan konsentrasi gliserin 10\%; F3 : Formula 3 mouthwash ekstrak kulit buah nanas dengan konsentrasi gliserin 15\%. 


\subsubsection{Evaluasi mutu fisik sediaan mouthwash.}

a. Pemeriksaan organoleptik. Evaluasi sediaan mouthwash dilakukan dengan mengamati bentuk, warna, bau, dan homogenitas. Pemeriksaan ini dilakukan pada suhu kamar. Pengujian dilakukan selama 21 hari (Depkes RI, 1995).

b. Pemeriksaan $p \mathrm{H}$. Pemeriksaan ini dilakukan menggunakan alat $p \mathrm{H}$ meter. $p \mathrm{H}$ sediaan obat kumur yang baik adalah mendekati $p \mathrm{H}$ mulut yang netral yaitu antara $p \mathrm{H}$ 6-7. Pengujian dilakukan selama 21 hari (Depkes RI, 1995).

c. Pemeriksaan viskositas. Pengukuran viskositas sediaan dilakukan menggunakan viskometer Ostwald. Waktu yang diperlukan cairan untuk mengalir dari batas atas hingga batas bawah dalam tabung dicatat sebagai waktu alir. Pengujian dilakukan selama 21 hari (Depkes RI, 1995).

$$
\text { Rumus }=\frac{\eta 1}{\eta 2}=\frac{t 1 . \rho 1}{t 2 . \rho 2}
$$

Keterangan :

$\eta 1=$ Viskositas sampel $(\mathrm{cP})$

$\eta 2=$ Viskositas air $(\mathrm{cP})$

@1 = Berat jenis sampel $(\mathrm{gram} / \mathrm{ml})$

@2 = Berat jenis air $(\mathrm{gram} / \mathrm{ml})$

t1 = Waktu alir sampel (detik)

t2 = Waktu alir air (detik)

d. Pemeriksaan stabilitas. Pemeriksaan stabilitas dilakukan dengan metode sentrifugasi pada kecepatan $3000 \mathrm{rpm}$ selama 30 menit. Hasil sentrifugasi dapat diamati dengan adanya pemisahan atau tidak (Kono, 2018).

\subsubsection{Sterilisasi}

Semua alat yang digunakan untuk penelitian dicuci bersih kemudian dikeringkan. Alat-alat gelas yang tidak tahan terhadap pemanasan dibungkus koran dan disterilisasi dengan autoclave pada suhu $121^{\circ} \mathrm{C}$ selama 15 menit. Untuk alat-alat gelas yang tahan terhadap pemanasan dibungkus koran dan disterilisasi dengan oven selama 1-2 jam. Bahan-bahan yang terbuat dari karet disterilkan dengan etanol 70\% dengan cara direndam. Sterilkan jarum ose dengan cara dipanaskan menggunakan lampu spiritus (Pratiwi, 2008).

\subsubsection{Peremajaan bakteri}

Koloni biakan bakteri Streptococcus mutans ATCC 25175 diambil menggunakan jarum ose, kemudian digoreskan pada media agar darah dan diinkubasi selama 24 jam pada suhu $37^{\circ} \mathrm{C}$ (Pratiwi, 2008).

\subsubsection{Pembuatan suspensi bakteri Streptococcus mutans ATCC 25175}

Pembuatan suspensi Streptococcus mutans ATCC 25175 dilakukan dengan cara mengambil 1 ose biakan murni dan dimasukan ke dalam tabung yang berisi media BHI (Brain Heart Infusion) kemudian diinkubasi pada suhu $37^{\circ} \mathrm{C}$ selama 24 jam. Kemudian biakan bakteri diambil dengan kawat ose steril lalu disuspensikan ke dalam tabung yang berisi $2 \mathrm{ml}$ larutan $\mathrm{NaCl}$ 0,9\% (0,18 gram dilarutkan dalam $20 \mathrm{ml}$ air). Suspensi bakteri yang telah dibuat disetarakan kekeruhannya dengan standar $M c$. Farland 0,5 atau sebanding dengan jumlah bakteri $10^{8}$ (CFU/ml) (Handayani et al., 2002).

\subsubsection{Identifikasi bakteri Streptococcus mutans ATCC 25175}

a. Identifikasi dengan media agar darah. Biakan ditanam pada media selektif agar darah atau sering disebut dengan media BAP, lalu diinkubasi selama 24 jam dengan suhu $37^{\circ} \mathrm{C}$. Hasil ditunjukkan dengan koloni berwarna hijau (hemolisis alfa) (Jawetz et al., 2007).

b. Identifikasi dengan pengecatan Gram. Dibuat preparat terlebih dahulu, kemudian dilanjutkan dengan pengecatan Gram A (crystal violet), Gram B (lugol iodin), Gram C (etanol:aseton $=1: 1)$, dan Gram D (safranin). Dilihat pada mikroskop dengan perbesaran 400x atau 1000x. Bakteri Streptococcus mutans ATCC 25175 merupakan bakteri Gram positif berwarna ungu (Fatimawali, 2016).

c. Identifikasi dengan uji biokimia. Identifikasi secara biokimia menggunakan uji katalase. Uji katalase dilakukan dengan cara satu ose bakteri dituangkan pada object glass yang telah terdapat $\mathrm{H}_{2} \mathrm{O}_{2} 3 \%$. Amati adanya gelembung gas atau tidak. Untuk Streptococcus mutans ATCC 25175 tidak ada gelembung atau negative (Toelle, 2014).

\subsubsection{Pembuatan media Mueller Hinton} Agar

Sebanyak 38 gram media dilarutkan dengan aqua destilata sebanyak $1000 \mathrm{ml}$. Diaduk hingga larut sempurna, kemudian media dipanaskan hingga mendidih. Media disterilkan dengan autoclave pada suhu 121 oC selama 15 menit. Media MHA yang sudah steril dituang pada cawan petri steril lalu didiamkan pada suhu kamar hingga memadat (Intan, 2017). 


\subsubsection{Pengujian antibakteri sediaan mouthwash}

Pengujian antibakteri sediaan mouthwash dilakukan dengan metode difusi sumuran. Metode difusi sumuran dilakukan dengan membuat suatu lubang menggunakan alat perforator dengan diameter tertentu pada media MHA yang telah ditanami bakteri uji. Masingmasing formula dimasukkan ke dalam lubang menggunakan alat perforator sebanyak $50 \mu \mathrm{l}$, kemudian diinkubasi pada suhu $37^{\circ} \mathrm{C}$ selama 24 jam. Luasnya zona bening menunjukan bahwa sediaan memiliki aktivitas antibakteri atau menunjukkan kepekaan bakteri terhadap sediaan antibakteri tersebut (Jawetz et al., 2007).

\subsubsection{Analisis data}

Data yang didapat disajikan dalam bentuk tabel dan grafik diolah dengan SPSS ver22 dengan metode Paired T-Test pada pengujian viskositas dan pengujian $\mathrm{pH}$ dan ANOVA pada pengukuran diameter zona hambat. Apabila data tidak terdistribusi normal, maka dilanjutkan dengan analisis Kruskal-Wallis, kemudian dilanjutkan dengan uji Mann-Whitney.

\section{Hasil Dan Pembahasan}

\subsection{Determinasi tanaman}

Hasil determinasi diketahui bahwa tanaman yang digunakan dalam penelitian merupakan benar spesies Ananas comosus (L.) Merr dari famili Bromeliaceae.

\subsection{Pembuatan serbuk kulit buah nanas}

Bahan baku kulit buah nanas dalam penelitian ini dipilih kulit buah nanas yang berwarna kuning matang dan dalam keadaan baik. Pada penelitian ini kulit buah nanas basah dengan bobot 8000 gram setelah dikeringkan hanya mendapatkan kulit buah nanas kering sebanyak 1550 gram dengan nilai rendemen sebesar 19,375\%. Hal ini dikarena terjadi penyusutan pada saat pengeringan sehingga kandungan air pada simplisia menjadi berkurang. Semakin lama pengeringan maka semakin banyak kandungan air yang hilang (Agoes, 2007). Kulit buah nanas kering kemudian dihaluskan dengan cara digiling dan didapatkan serbuk kulit buah nanas sebanyak 1250 gram dengan nilai rendemen sebesar $80,645 \%$.

\subsection{Pemeriksaan serbuk kulit buah nanas}

1.3.1 Pemeriksaan organoleptik. Pemeriksaan ini bertujuan untuk mengetahui sifat fisik dan sebagai kontrol kualitas serbuk baik dari segi bentuk, warna, bau, dan rasa. Serbuk kulit buah nanas berbentuk serbuk halus, berwarna coklat, berbau khas nanas, dan tidak berasa.

1.3.2 Pemeriksaan kelembaban serbuk. Pemeriksaan ini bertujuan untuk mengetahui rentang besarnya senyawa yang hilang pada proses pengeringan. Kadar lembab dari serbuk kulit buah nanas yaitu 6,36\%. Hal tersebut menunjukkan bahwa serbuk kulit buah nanas yang didapat memiliki kadar lembab yang masih memenuhi standar ketentuan yaitu dibawah $10 \%$.

\subsection{Ekstraksi serbuk kulit buah nanas} Pada proses ekstraksi menggunakan serbuk sebanyak 1000 gram. Hasil ekstraksi serbuk kulit buah nanas (Ananas comosus (L.) Merr) diperoleh ekstrak kental sebanyak 642 gram dengan nilai rendemen sebesar $64,2 \%$. Rendemen merupakan perbandingan dari bobot ekstrak yang diperoleh dengan bobot simplisia awal (Depkes RI 1986).

\subsection{Pemeriksaan eksrak kulit buah} nanas

\subsubsection{Pemeriksaan organoleptik.}

Pemeriksaan ini bertujuan untuk mengetahui sifat fisik dan sebagai kontrol kualitas ekstrak baik dari segi bentuk, warna, bau, dan rasa. Ekstrak kulit buah nanas berbentuk ekstrak kental, berwarna coklat kehitaman, berbau khas nanas, dan berasa pahit.

1.5.2 Pemeriksaan kadar air ekstrak. Tujuan pemeriksaan ini untuk mengetahui kadar air yang terkandung di dalam ekstrak. Rata-rata yang didapatkan dari hasil penetapan kadar air ekstrak kulit buah nanas sebesar 4,049\%. Semakin tinggi kadar air dalam suatu ekstrak dapat menyebabkan ekstrak mudah terkontaminasi oleh mikroba. Pengujian kadar air termasuk dalam parameter non spesifik yang dapat mempengaruhi keamanan dan stabilitas dari suatu ekstrak (Saifudin et al., 2011).

Pemeriksaan kandungan kimia ekstrak. Pemeriksaan ini dilakukan secara kualitatif menggunakan uji tabung dengan tujuan untuk mengetahui kandungan flavonoid, tanin, saponin, alkaloid, dan bromelain dari ekstrak kulit buah nanas 
Tabel 2. Pemeriksaan kandungan kimia ekstrak kulit buah nanas

\begin{tabular}{ccc}
\hline Kandungan kimia & Hasil & Interpretasi hasil \\
\hline Flavonoid & Terbentuk warna merah & + \\
Tanin & Terbentuk warna hijau kehitaman & + \\
& Reagen Mayer terbentuk endapan putih & + \\
Alkaloid & Reagen Bouchardat terbentuk endapan coklat & \\
& Reagen Dragendorff terbentuk endapan jingga & + \\
Saponin & Terbentuk busa stabil & + \\
Bromelain & Terbentuk warna ungu & + \\
\hline
\end{tabular}

Berdasarkan hasil pemeriksaan kandungan kimia dengan uji kualitatif dengan metode uji tabung terhadap ekstrak kulit buah nanas pada tabel 2 dapat diketahui bahwa ekstrak kulit buah nanas positif mengandung senyawa flavonoid, tanin, saponin, alkaloid, dan bromelain.

1.6. Pengujian mutu fisik mouthwash

\section{Ekstrak kulit buah nanas}

1.6.1 Pengujian organoleptik. Pengujian organoleptik dilakukan untuk mendeskripsikan bentuk, warna, bau, dan homogenitas dari sediaan mouthwash. Pengujian ini dilakukan melalui pengamatan langsung menggunakan indera penglihatan. Sediaan mouthwash diharapkan memiliki bentuk berupa cairan sehingga nyaman digunakan dan dapat merata pada rongga mulut, memiliki warna yang menarik, dan bau yang menyenangkan. Pada pengujian organoleptik didapatkan bentuk berupa cairan, berwarna coklat, berbau khas nanas, dan homogen. Pada pengujian hari ke-1 hingga hari ke-21 tidak menunjukkan adanya perubahan dari segi bentuk, warna, bau, dan homogenitas, sehingga stabil dalam penyimpanan. Hasil pengujian organoleptik dapat dilihat pada tabel 3 .

Tabel 3. Hasil pengujian organoleptik mouthwash ekstrak kulit buah nanas

\begin{tabular}{ccccccc}
\hline \multirow{2}{*}{ Pengujian } & Waktu & \multicolumn{5}{c}{ Organoleptik } \\
\cline { 2 - 6 } & & K - & K+ & F1 & F2 & F3 \\
\hline Bentuk & 1 & Cairan & Cairan & Cairan & Cairan & Cairan \\
& 7 & Cairan & Cairan & Cairan & Cairan & Cairan \\
& 14 & Cairan & Cairan & Cairan & Cairan & Cairan \\
Warna & 21 & Cairan & Cairan & Cairan & Cairan & Cairan \\
& 1 & Putih & Biru jernih & Coklat & Coklat & Coklat \\
& 7 & Putih & Biru jernih & Coklat & Coklat & Coklat \\
& 14 & Putih & Biru jernih & Coklat & Coklat & Coklat \\
Bau & 21 & Putih & Biru jernih & Coklat & Coklat & Coklat \\
& 1 & Khas & Khas & Khas & Khas & Khas \\
& 7 & Khas & Khas & Khas & Khas & Khas \\
& 14 & Khas & Khas & Khas & Khas & Khas \\
& 21 & Khas & Khas & Khas & Khas & Khas \\
Homogenitas & 1 & Homogen & Homogen & Homogen & Homogen & Homogen \\
& 7 & Homogen & Homogen & Homogen & Homogen & Homogen \\
& 14 & Homogen & Homogen & Homogen & Homogen & Homogen \\
& 21 & Homogen & Homogen & Homogen & Homogen & Homogen \\
\hline
\end{tabular}

Keterangan

K- : Kontrol negatif (sediaan mouthwash tanpa ekstrak) dengan konsentrasi gliserin 5\%; K+ : Kontrol positif colgate; F1: Formula 1 mouthwash ekstrak kulit buah nanas dengan konsentrasi gliserin 5\%; F2 : Formula 2 mouthwash ekstrak kulit buah nanas dengan konsentrasi gliserin 10\%; F3 : Formula 3 mouthwash ekstrak kulit buah nanas dengan konsentrasi gliserin 15\%

1.6.2 Pengujian viskositas. Pengujian viskositas bertujuan untuk mengetahui konsistensi atau kekentalan suatu sediaan. Sediaan mouthwash yang baik memiliki viskositas yang rendah mendekati viskositas air yaitu berkisar 1.0-1.5 cP (Pradewa, 2008). Nilai viskositas sediaan mouthwash ditentukan oleh bahan-bahan yang terkandung dalam formula seperti gliserin. Semakin tinggi konsentrasi gliserin yang digunakan, maka semakin kental sediaan mouthwash yang dihasilkan. Berdasarkan hasil yang didapat terjadi perbedaan nilai viskositas yang berbeda antar formula yang disebabkan oleh variasi penggunaan gliserin 
pada setiap formula. Hasil evaluasi viskositas sediaan mouthwash pada semua formula mengalami penurunan dari hari ke-1 hingga hari ke-21. Penurunan nilai viskositas disebabkan karena faktor penyimpanan, yakni suhu serta tekanan. Hasil pengujian viskositas dapat dilihat pada tabel 4. Data pengujian viskositas dianalisis menggunakan SPSS dengan metode ShapiroWilk diperoleh hasil bahwa data pengujian viskositas terdistribusi normal yang dibuktikan pada nilai signifikansi dari semua formula pada hari ke-1, ke-7, ke-14, dan ke-21 adalah > 0,05, kemudian dilanjutkan uji statistik menggunakan metode Paired Sample T-Test untuk mengetahui perbedaan yang signifikan (sig 2-tailed). Pada uji statistik menggunakan metode Paired Sample TTest apabila nilai signifikansi $<$ dari 0,05 maka terdapat perbedaan yang signifikan dan apabila nilai signifikansi $>0,05$ maka tidak terdapat perbedaan yang signifikan.

Tabel 4. Hasil pengujian viskositas mouthwash ekstrak kulit buah nanas

\begin{tabular}{ccccc}
\hline \multirow{2}{*}{ Formula } & \multicolumn{4}{c}{ Viskositas (cP) } \\
\cline { 2 - 5 } & Hari ke-1 & Hari ke-7 & Hari ke-14 & Hari ke-21 \\
\hline K- & $1,1267 \pm 0,0062$ & $1,0989 \pm 0,0062$ & $1,0565 \pm 0,0040$ & $1,0312 \pm 0,0060$ \\
K+ & $1,1430 \pm 0,0041$ & $1,1305 \pm 0,0041$ & $1,1038 \pm 0,0041$ & $1,0865 \pm 0,0041$ \\
F1 & $1,1397 \pm 0,0041$ & $1,1203 \pm 0,0041$ & $1,0941 \pm 0,0041$ & $1,0575 \pm 0,0040$ \\
F2 & $1,1720 \pm 0,0041$ & $1,1573 \pm 0,0041$ & $1,1216 \pm 0,0062$ & $1,0956 \pm 0,0041$ \\
F3 & $1,2109 \pm 0,0083$ & $1,2070 \pm 0,0063$ & $1,1848 \pm 0,0041$ & $1,1784 \pm 0,0041$ \\
\hline
\end{tabular}

Keterangan

$\mathrm{K}-$ : Kontrol negatif (sediaan mouthwash tanpa ekstrak) dengan konsentrasi gliserin $5 \% ; \mathrm{K}+$ : Kontrol positif colgate; F1: Formula 1 mouthwash ekstrak kulit buah nanas dengan konsentrasi gliserin 5\%; F2 : Formula 2 mouthwash ekstrak kulit buah nanas dengan konsentrasi gliserin 10\%; F3 : Formula 3 mouthwash ekstrak kulit buah nanas dengan konsentrasi gliserin $15 \%$.

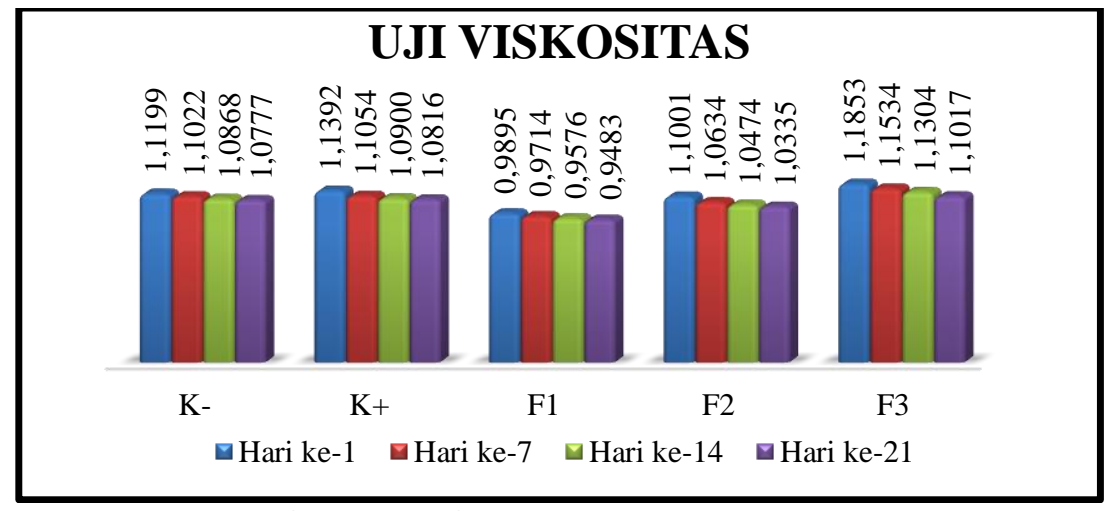

Gambar 1 Grafik data uji viskositas

1.6.3 Pengujian $p \mathbf{H}$. Pengujian $p \mathrm{H}$ bertujuan untuk mengetahui derajat keasaman sediaan mouthwash yang telah dibuat apakah memenuhi $p \mathrm{H}$ standar pada rongga mulut yaitu 6-7 atau tidak (Pontefract, 2001). Evaluasi $p \mathrm{H}$ sediaan moutbwash dilakukan selama 21 hari. Hasil evaluasi $p \mathrm{H}$ sediaan mouthwash pada semua formula mengalami penurunan dari hari ke-1 hingga hari ke-21. Penurunan nilai $p \mathrm{H}$ sediaan moutbwash setiap minggu disebabkan oleh beberapa faktor seperti suhu, penyimpanan, dan sensitivitas dari alat $\mathrm{pH}$ meter yang digunakan (Young, 2002). Hasil evaluasi $p \mathrm{H}$ sediaan mouthwash terdapat perbedaan antara kontrol dan F1-F3 bahwa pada kontrol negatif dan kontrol positif nilai $p \mathrm{H}$ dari sediaan mouthwash memenuhi $p \mathrm{H}$ standar pada rongga mulut yaitu berkisar antara 6-7, sedangkan pada F1, F2, dan $\mathrm{F} 3$ nilai $\mathrm{pH}$ yang dihasilkan tidak memenuhi $\mathrm{pH}$ standar pada rongga mulut. Hal tersebut disebabkan oleh penambahan dari ekstrak kulit buah nanas pada formula sediaan mouthwash yang bersifat asam. Terdapat kandungan dari buah nanas yang memiliki sifat asam yaitu vitamin $C$ sehingga dengan penambahan ekstrak kulit buah nanas $\mathrm{pH}$ yang didapat bersifat asam. Hasil pengujian $\mathrm{pH}$ dapat dilihat pada tabel 5 . Data pengujian $\mathrm{pH}$ dianalisis menggunakan SPSS dengan metode Shapiro-Wilk diperoleh hasil bahwa data pengujian $\mathrm{pH}$ terdistribusi normal yang dibuktikan pada nilai signifikansi dari semua formula pada hari ke-1, ke-7, ke-14, 
dan ke-21 adalah $>0,05$. Dilanjutkan uji statistik menggunakan metode Paired Sample T-Test, $\mathrm{pH}$ sediaan mouthwash ekstrak kulit buah nanas menunjukkan perbedaan yang signifikan dari hari ke-1, hari ke-7, hari ke-14, dan hari ke-21 yang dibuktikan pada nilai signifikansi yaitu < 0,05. Hal tersebut dapat disimpulkan bahwa $\mathrm{pH}$ masing-masing formula dan kontrol sediaan mouthwash tidak stabil dalam penyimpanan selama 21 hari.

Tabel 5. Hasil pengujian $p H$ mouthwash ekstrak kulit buah nanas

\begin{tabular}{ccccc}
\hline Formula & \multicolumn{4}{c}{$\mathbf{p H}$} \\
\cline { 2 - 5 } & Hari ke-1 & Hari ke-7 & Hari ke-14 & Hari ke-21 \\
\hline K- & $6,51 \pm 0,0100$ & $6,47 \pm 0,0200$ & $6,33 \pm 0,0252$ & $6,22 \pm 0,0100$ \\
K+ & $6,32 \pm 0,0208$ & $6,29 \pm 0,0153$ & $6,22 \pm 0,0265$ & $6,17 \pm 0,0153$ \\
F1 & $4,45 \pm 0,0153$ & $4,36 \pm 0,0141$ & $4,22 \pm 0,0200$ & $4,17 \pm 0,0153$ \\
F2 & $4,48 \pm 0,0100$ & $4,38 \pm 0,0100$ & $4,26 \pm 0,0153$ & $4,22 \pm 0,0153$ \\
F3 & $4,53 \pm 0,0153$ & $4,46 \pm 0,0252$ & $4,34 \pm 0,0200$ & $4,29 \pm 0,0100$ \\
\hline
\end{tabular}

Keterangan

K- : Kontrol negatif (sediaan mouthwash tanpa ekstrak) dengan konsentrasi gliserin 5\%; K+ : Kontrol positif colgate; F1: Formula 1 mouthwash ekstrak kulit buah nanas dengan konsentrasi gliserin 5\%; F2 : Formula 2 mouthwash ekstrak kulit buah nanas dengan konsentrasi gliserin 10\%; F3 : Formula 3 mouthwash ekstrak kulit buah nanas dengan konsentrasi gliserin $15 \%$.

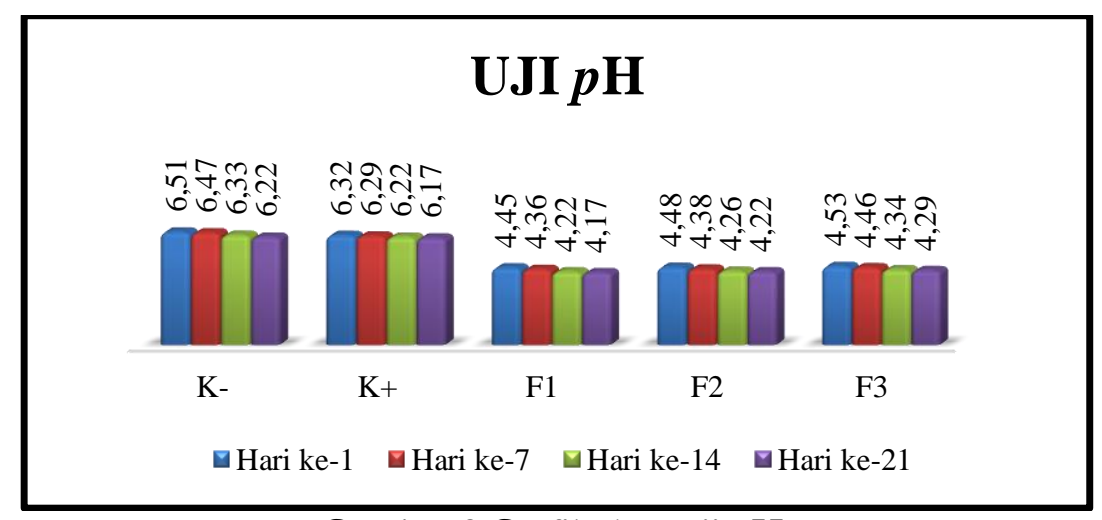

Gambar 2 Grafik data uji $p H$.

1.6.4 Pengujian stabilitas. Pengujian ini bertujuan untuk mengetahui apakah sediaan mouthwash yang dibuat mengalami pemisahan fase atau tidak. Sediaan yang baik tidak akan mengalami pemisahan fase atau stabil karena akan berpengaruh terhadap jangka panjang penggunaan dan menurunnya khasiat dari sediaan tersebut. Hasil pengujian stabilitas sediaan mouthwash dapat dilihat pada tabel 6 .

Tabel 6. Hasil pengujian stabilitas mouthwash ekstrak kulit buah nanas

\begin{tabular}{cc}
\hline Formula & Stabilitas \\
\hline $\mathrm{K}-$ & Tidak mengalami pemisahan fase \\
$\mathrm{K}+$ & Tidak mengalami pemisahan fase \\
F1 & Tidak mengalami pemisahan fase \\
F2 & Tidak mengalami pemisahan fase \\
F3 & Tidak mengalami pemisahan fase \\
\hline
\end{tabular}

Keterangan

K- : Kontrol negatif (sediaan mouthwash tanpa ekstrak); K+ : Kontrol positif colgate; F1: Formula 1 mouthwash ekstrak kulit buah nanas dengan konsentrasi gliserin 5\%; F2 : Formula 2 mouthwash ekstrak kulit buah nanas dengan konsentrasi gliserin 10\%; F3 : Formula 3 mouthwash ekstrak kulit buah nanas dengan konsentrasi gliserin 15\%. 


\subsection{Pengujian antibakteri mouthwash ekstrak kulit buah nanas}

1.7.1 Identifikasi bakteri. Identifikasi bakteri Streptococcus mutans ATCC 25175 meliputi identifikasi bakteri pada media agar darah, identifikasi bakteri dengan pengecatan Gram, dan identifikasi bakteri secara biokimia menggunakan uji katalase. Hasil identifikasi bakteri dapat lihat pada tabel 7. Pada pengujian media agar darah terjadi hemolisis $\alpha$ yang merupakan melisisnya sebagian sel darah merah yang disebabkan oleh reduksi hemoglobin sehingga membuat koloni bakteri menjadi berwarna hijau pada media agar darah. Pada identifikasi dengan pengecatan gram, koloni berwarna ungu yang berarti Gram + dan berbentuk coccus atau bulat. Dan pada identifikasi dengan uji katalase menunjukkan hasil negatif tidak terbentuk gelembung gas yang menunjukkan bahwa bakteri Streptococcus mutans ATCC 25175 tidak memiliki enzim katalase yang dapat memcah $\mathrm{H}_{2}$ menjadi $\mathrm{O}_{2}$.

Tabel 7. Hasil identifikasi bakteri Streptococcus mutans ATCC 25175

\begin{tabular}{ccc}
\hline Identifikasi & Hasil & Interpretasi hasil \\
\hline Media agar darah & Koloni berwarna hijau $($ Hemolisis $\alpha)$ & + \\
Pengecatan Gram & Koloni berwarna ungu $($ Gram +$)$ & + \\
Uji katalase & Tidak terbentuk gelembung gas & - \\
\hline
\end{tabular}

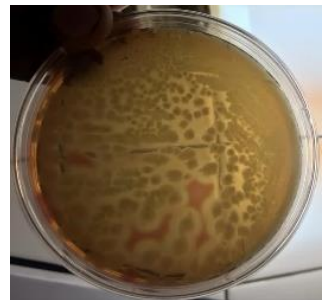

Gambar 3 Identifikasi pada media agar darah (Hemolisis $\alpha)$.

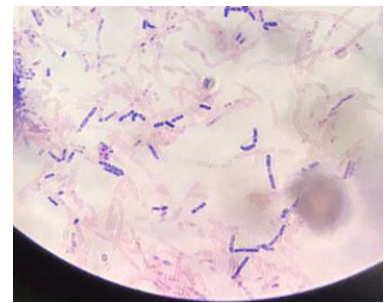

Gambar 4 Identifikasi dengan pengecatan Gram (Perbesaran 100x).

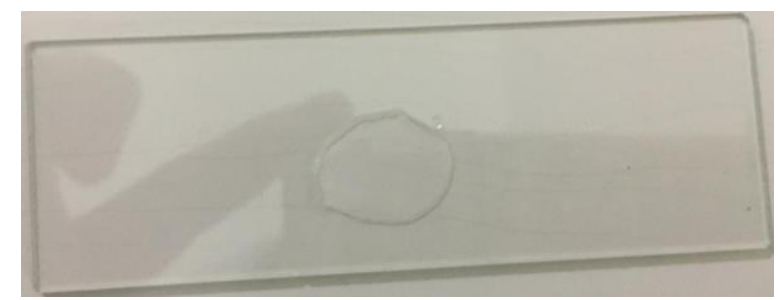

Gambar 5 Identifikasi dengan uji biokimia.

1.7.2 Pengujian antibakteri sediaan mouthwash. Pengujian aktivitas antibakteri Streptococcus mutans ATCC 25175 dilakukan dengan metode difusi sumuran. Zona bening yang terbentuk di sekitar sumuran menunjukkan bahwa sediaan moutbwash ekstrak kulit buah nanas dapat menghambat atau memiliki aktivitas antibakteri terhadap Streptococcus mutans ATCC 25175. Variasi konsentrasi gliserin dalam formula mempengaruhi aktivitas antibakteri, hal ini ditunjukkan pada hasil diameter zona hambat yang terbentuk. Semakin tinggi penambahan gliserin maka semakin besar diameter zona hambat. Hasil penelitian menunjukkan bahwa semua sediaan mouthwash yang diuji mampu menghambat pertumbuhan bakteri Streptococcus mutans ATCC 25175 dengan kategori kuat. Hasil pengujian antibakteri dapat dilihat pada tabel 8 . Dilakukan pengujian statistik menggunakan metode Shapiro-Wilk diperoleh hasil bahwa data terdistribusi normal yang dibuktikan pada nilai $>0,05$. Kemudian dilanjutkan uji Levene Test untuk mengetahui homogenitas, diperoleh hasil data homogen yang ditunjukkan dengan nilai signifikansi $>0,05$. Data homogen kemudian dilanjutkan uji statistik menggunakan One-Way Anova, Tukey HSD. Pada formula 1, formula 2, dan, formula 3 tidak berada dalam satu subset dengan kontrol negatif yang tidak memiliki aktivitas sebagai antibakteri. Formula 3 berada dalam satu subset dengan kontrol positif, yang artinya formula 3 memiliki daya hambat sama dengan kontrol positif dan dapat dikatakan bahwa formula 3 merupakan formula yang 
paling efektif dilihat pada hasil evaluasi mutu fisik sediaan mouthwash, formula 3 memiliki mutu fisik yang paling bagus dan memenuhi syarat sediaan mouthwash.

Tabel 8. Hasil diameter zona hambat

\begin{tabular}{ccccc}
\hline Sampel & \multicolumn{3}{c}{ Diameter zona hambat $\mathbf{( m m})$} & \multirow{2}{*}{ Rata-rata \pm SD } \\
\cline { 2 - 4 } & I & II & III & \\
\hline K (-) & 0 & 0 & 0 & 0 \\
K (+) & 16,00 & 16,50 & 17,75 & $16,75 \pm 0,901$ \\
F1 & 10,75 & 11,50 & 11,00 & $11,08 \pm 0,382$ \\
F2 & 12,25 & 13,75 & 13,25 & $13,08 \pm 0,764$ \\
F3 & 14,50 & 15,75 & 15,00 & $15,08 \pm 0,629$ \\
\hline
\end{tabular}

Keterangan

K- : Kontrol negatif (sediaan mouthwash tanpa ekstrak); K+ : Kontrol positif colgate; F1: Formula 1 mouthwash ekstrak kulit buah nanas dengan konsentrasi gliserin 5\%; F2 : Formula 2 mouthwash ekstrak kulit buah nanas dengan konsentrasi gliserin 10\%; F3 : Formula 3 mouthwash ekstrak kulit buah nanas dengan konsentrasi gliserin 15\%.

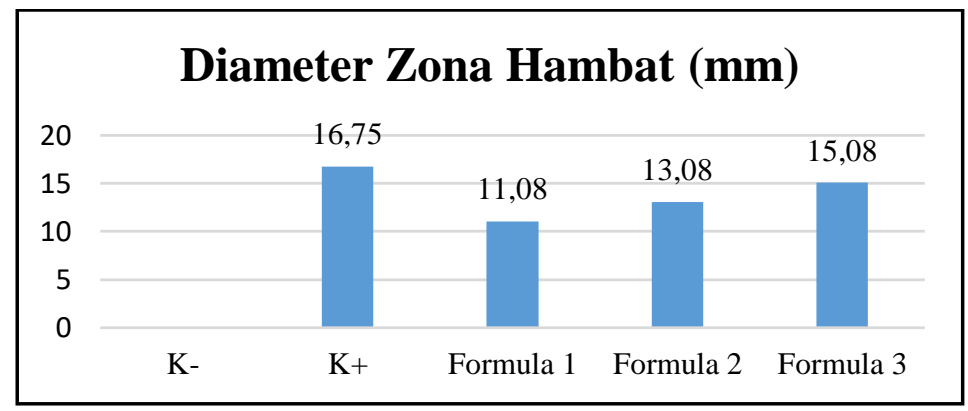

Gambar 6 Grafik data uji aktivitas antibakteri.

\section{Kesimpulan}

Berdasarkan hasil penelitian yang telah dilakukan dapat disimpulkan bahwa:

Pertama, variasi konsentrasi gliserin berpengaruh terhadap mutu fisik organoleptik, viskositas, $p \mathrm{H}$, stabilitas, dan aktivitas antibakteri pada sediaan moutbwash ekstrak kulit buah nanas (Ananas comosus (L.) Merr) terhadap Streptococcus mutans ATCC 25175.

Kedua, diketahui bahwa formula yang menghasilkan sediaan mouthwash ekstrak kulit buah nanas (Ananas comosus (L.) Merr) dengan mutu fisik organoleptik, viskositas, $p \mathrm{H}$, stabilitas, dan aktivitas antibakteri terhadap Streptococcus mutans ATCC 25175 yang paling baik adalah formula 3 dengan konsentrasi gliserin sebesar 15\%.

\section{Ucapan Terimakasih}

Penulis mengucapkan terima kasih kepada Allah SWT, kedua orang tua, keluarga besar, teman teman yang tidak bisa penulis sebutkan satu persatu, dan seluruh civitas akademika Universitas Setia Budi Surakarta yang telah membimbing, membantu, dan memberikan semangat motivasi dalam pengerjaan penelitian ini.

\section{Daftar Pustaka}

Agoes, G. 2007. Teknologi Bahan Alam. ITB. Bandung.

Akarina, W. 2011. Pengaruh Konsentrasi Humektan terhadap Stabilitas Formula Obat Kumur. Jurnal USU.

Angraeni, D. P. dan A. D. Rahmawati. 2014. Efektivitas Daya Antibakteri Ekstrak Kulit Nanas (Ananas comosus) Terhadap Pertumbuhan Streptococcus mutans ATCC 25175. Karya Tulis Ilmiah. Universitas Muhammadiyah Yogyakarta.

Baitariza, A., A. Ghazali, dan R. Rosmiati. 2020. Formulasi Larutan Obat Kumur Pencegah Plak Gigi Ekstrak Kulit Nanas (Ananas comosus L. Merr). Jurnal Sabdariffarma 1(2).

Departemen Kesehatan Republik Indonesia. 1986. Sediaan Galenik. DepKes RI. Jakarta.

Departemen Kesehatan Republik Indonesia. 1995. Farmakope Indonesia. Edisi IV. DepKes RI. Jakarta. 
Departemen Kesehatan Republik Indonesia. 2000. Parameter Standar Umum Ekstrak Tumbuhan Obat. DepKes RI. Jakarta.

Dewi, R. S. 2019. Penggunaan Obat Tradisional Oleh Masyarakat di Kelurahan Tuah Karya Kota Pekanbaru. Jurnal Penelitian Farmasi Indonesia, 8(1):41-45.

Fatimawali. 2016. Toksikologi Detoksifikasi Merkuri. Unsrat Press. Manado.

Jawetz, E., J. L. Melnick, dan E. A. Adelberg. 2007. Mikrobiologi Kedokteran. Diterjemahkan oleh Bagian Mikrobiologi Fakultas Kedokteran Universitas Airlangga. Salemba Medika. Jakarta.

Kementerian Kesehatan Republik Indonesia. 2017. Farmakope Herbal Indonesia. Edisi II. Kementerian Kesehatan RI. Jakarta.

Kidd, E. A. M. dan S. J. Bechal. 1992. DasarDasar Karies Penyakit dan Penanggulangannya. Terjemahan Naran Sumawinata \& Safrida Faruk. EGC. Jakarta.

Kono, S. R. 2018. Formulasi Sediaan Obat Kumur Herba Patikan Kebo (Euphorbia hirta) Dan Uji Antibakteri Prophyromonas gingivalis. Pharmacon $7(1)$.

Pambudi, Y. B. 2017. Uji Aktivitas Antioksidan dan Penetapan Kadar Bromelain Terhadap Bovine Serum Albumin (BSA) Dari Ekstrak Kulit Buah Nanas (Ananas comosus L. Merr). Skripsi. Fakultas Farmasi Universitas Sanata Dharma. Yogyakarta.
Pontefract. 2001. The Erosive Effects of Some Mouthrinses on enamel. A Study in Situ. Journal of Clinical Periodontology 28(4): 283-376.

Pradewa, R. 2008. Formulasi Formula Obat Kumur Berbahan Dasar Gambir. Jurnal IPB. Bogor.

Saifudin, A., Rahayu, dan Teruna. 2011. Standarisasi Bahan Obat Alam Graha ilmu. Yogyakarta.

Sangi, M., M. R. J. Runtuwene, H. M. I. Simbala, dan V. M. A. Makang. 2008. Analisis Fitokimia Tumbuhan Obat Di Kabupaten Minahasa Utara. Chem Prog 1( 1): 47-53.

Setiawan, M. H., S. Mursiti, dan E. Kusumo. 2016. Isolasi Dan Uji Daya Antimikroba Ekstrak Kulit Nanas (Ananas comosus L. Merr). Jurnal Mipa 39(2): 128-134.

Toelle, N. N. Dan V. Lenda. 2014. Identifikasi dan Karakteristik Staphylococcus Sp dan Streptococcus Sp dari Infeksi Ovarium pada Ayam Petelur.

Utami, P. Y., B. Taebe, dan Fatmawati. 2016. Standarisasi Parameter Spesifik Dan Non Spesifik Ekstrak Etanol Daun Murbei (Morus Alba L.) Asal Kabupaten Soppeng Provinsi Sulawesi. Journal of pharmaceutical and medicinal sciences 1(2): 48-52.

WHO.2012. Oral health. http://www.who.int/ mediacentre/factsheets/fs318/en/. 23 September 2020 (20.17).

Young, A. 2002. Practical Cosmetic Science, 3940. Mills and Boon Limited. London 